\title{
Article \\ High Genetic Diversity and Low Population Differentiation in Wild Hop (Humulus lupulus L.) from Croatia
}

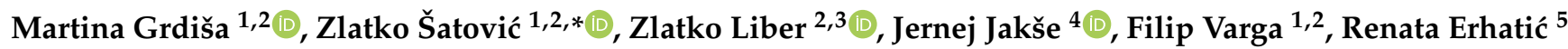 \\ and Siniša Srečec ${ }^{5}$ \\ 1 Faculty of Agriculture, University of Zagreb, Svetošimunska Cesta 25, 10000 Zagreb, Croatia; \\ mgrdisa@agr.hr (M.G.); fvarga@agr.hr (F.V.) \\ 2 Centre of Excellence for Biodiversity and Molecular Plant Breeding (CoE CroP-BioDiv), \\ Svetošimunska Cesta 25, 10000 Zagreb, Croatia; zlatko.liber@biol.pmf.hr \\ 3 Faculty of Science, University of Zagreb, Marulićev Trg 9a, 10000 Zagreb, Croatia \\ 4 Biotechnical Faculty, University of Ljubljana, Jamnikarjeva 101, 1000 Ljubljana, Slovenia; \\ Jernej.Jakse@bf.uni-lj.si \\ 5 Križevci College of Agriculture, Milislava Demerca 1, 48260 Križevci, Croatia; rerhatic@vguk.hr (R.E.); \\ ssrecec@vguk.hr (S.S.) \\ * Correspondence: zsatovic@agr.hr
}

check for updates

Citation: Grdiša, M.; Šatović, Z.; Liber, Z.; Jakše, J.; Varga, F.; Erhatić, R.; Srečec, S. High Genetic Diversity and Low Population Differentiation in Wild Hop (Humulus lupulus L.) from Croatia. Appl. Sci. 2021, 11, 6484. https://doi.org/ 10.3390/app11146484

Academic Editors: Tommaso Ganino, Andrea Fabbri and Margherita Rodolfi

Received: 21 June 2021

Accepted: 11 July 2021

Published: 14 July 2021

Publisher's Note: MDPI stays neutral with regard to jurisdictional claims in published maps and institutional affiliations.

Copyright: (c) 2021 by the authors. Licensee MDPI, Basel, Switzerland. This article is an open access article distributed under the terms and conditions of the Creative Commons Attribution (CC BY) license (https:/ / creativecommons.org/licenses/by/ $4.0 /)$.
Abstract: Hop (Humulus lupulus L.) is used in the brewing industry as a source of compounds responsible for the bitterness, aroma, and preservative properties of beer. In this study, we used microsatellite markers to investigate genetic diversity and genetic differentiation of wild hop populations sampled in the northwestern part of Croatia. Analysis of 12 microsatellite loci revealed high diversity and weak population differentiation among wild hop populations. A total of 152 alleles were determined with an average of 12.67 alleles per locus. Observed heterozygosity ranged from 0.689 to 0.839 (average 0.767 ) and expected heterozygosity ranged from 0.725 to 0.789 (average 0.760 ). A total of 38 private alleles were detected. The data suggest that H. lupulus populations are not affected by recent bottlenecks. The degree of genetic differentiation among populations was low and not significant for most pairwise $F_{S T}$ values, except for the pair of geographically most distant populations. The results did not indicate the existence of genetic structure among the sampled populations. The high genetic diversity and low differentiation among populations, combined with the absence of isolation by distance, indicate the existence of substantial gene flow among wild hop populations. Therefore, extensive sampling per population is clearly required to assess the genetic diversity of hop populations. Sampling strategies involving sampling across a large number of localities represented by only a few samples could lead to erroneous conclusions.

Keywords: genetic diversity and structure; genetic resources; Humulus lupulus L.; SSR; wild germplasm

\section{Introduction}

Hop (Humulus lupulus L.) is a dioecious, perennial, wind-pollinated climbing plant species which belongs to the family Cannabinaceae. Generally, wild hop populations inhabit marshy or wet depressions in fens and moist alder-oak woodlands [1]. It is native to North America, Southeast Asia, and Europe [2]. In wild hop, five taxonomic varieties are distinguished on the basis of leaf morphology and geographical distribution: var. lupulus for European hop, var. cordifolius for Japanese hop, and var. neomexicanus, pubescens, and lupuloides for North American hop [3]. Wild hop populations have been collected from their natural habitat since ancient times. Higher demands on the plant and consequently its introduction into cultivation began in the 12th century when it became widely used as a preservative and clarifier in the brewing process of beer $[4,5]$. It was domesticated mainly in Central Europe [6] and the first plantations were established with several wild and adapted genotypes with desirable traits, propagated with cuttings [7]. The noble 
cultivars Saaz, Spalt, Tettnanger, and Hallertauer Mittelfrueh are descended from these genotypes [8]. They represent typical European aroma hop, with a relatively low yield and resin content [9]. In hop, female and male plants are distinguished on the basis of flower morphology. Female plants are pollinated by wind [7]. Exclusively female flowers are of economic value as they develop umbels with numerous lupulin glands on their bracts [10], which produce secondary metabolites used as flavoring agents in beer brewing to add bitterness and aroma [11,12]. Secondary metabolites include resins, essential oils, and tannins [7]. Resins include hard resins (xanthohumol and iso-xanthohumol), flavones, and soft resins (hop acids) dominated by humulones ( $\alpha$-acids) and lupulones ( $\beta$-acids) [13]. Both $\alpha$-and $\beta$-acids provide the bitter taste of beer, while $\beta$-acids also provide the preservative effect [7]. Essential oils of hop are responsible for the taste and aroma of beer and their main components are mircenes and humulene [6,14]. Secondary hop metabolites also show potent antibacterial, antifungal, antifungal, antiviral, antiparasitic [15,16], estrogenic [6], and anticancer activity [17], thus could be used for nonbrewing purposes. A number of studies have focused on identifying chemical profiles of hop $[18,19]$ and hop aroma in beer [20-24]. Hop genotypes differ in the presence, amount and relative proportion of secondary metabolites and consequently in aroma, bitterness and flavor [25], which offers great potential for the development of new varieties. Apart from different chemical profiles and higher content and quality of metabolites accumulated in lupulin glands [26] and desirable brewing property, modern breeding programs are constantly searching for new plant varieties with higher yield per hectare and resistance to diseases $[27,28]$. They involve hybridization and the basic source of plant material (wild hop, cultivars, breeding lines) is maintained in established large hop breeding centers. Due to their dioecious nature, hop plants are unable to self-fertilize and plants grown from seed are naturally very heterozygous and rarely resemble either parent. Therefore, hop is commercially clonally propagated, which maintains clonal fidelity and specific brewing characteristics [29,30]. Genetic variation in wild hops and hop cultivars has been studied using a variety of molecular tools, allowing their molecular characterization and identification of their genetic relationship. The studies that aimed to unravel the extent of genetic diversity and differentiation among hop cultivars mostly reported a clear separation into clusters based on their geographical origin. One such study is that of Šuštar-Vozlič and Javornik [31] who used RAPD (Random Amplified Polymorphic DNA) markers to conduct a broad study of 65 cultivars, from the major growing regions of the world and determined their grouping into European and North American cluster. Murakami [32] analyzed 51 hop cultivars and identified six clusters consistent with their breeding history and geographical origin. Henning et al. [33] used Amplified Fragment Length Polymorphism markers (AFLP) to examine the genetic diversity of world accessions grown in the United States based on yield, hop storage index and essential oil chemical composition and grouped them into three clusters; European, North American, and hybrid. In the study by Seefelder et al. [34], AFLP analysis distinguished two major clusters; the first consisted of European accessions and the second of accessions of European origin mixed with wild American hops.

Wild hop populations have been the focus of research by several authors. Murakami et al. [35] analyzed 133 wild hops from North America, Europe, and Asia using $11 \mathrm{mi}-$ crosatellite loci (SSR; Simple Sequence Repeats), while Patzak et al. [8] performed chemical and molecular analyzes using SSR and STS (Sequence-Tagged Site) on 136 hop genotypes from Czech Republic, France, Switzerland, and the Caucasus. Both studies allowed the distinction of two clusters, North American and Eurasian, and a lower genetic variability of the Eurasian wild accessions. In 2010, Patzak et al. [36] conducted a more comprehensive study in which they examined genetic variability by utilizing SSRs and STSs, and chemical diversity in European, Caucasian, Canadian, and North American wild hop. Based on chemical data, North American and European groups were distinguished, while molecular analysis separated Caucasian and European wild accessions. Italian wild hop accessions were studied by Riccioni et al. [37]. Mafakheri et al. [38] used SSR, RAPD, and ISSR markers 
to assess the genetic diversity and structure of 15 wild $H$. lupulus populations sampled in the Hyrcanian forests in Northern Iran.

The comparative studies on wild and cultivated hop are also available. Jakše et al. [39] analyzed genetic diversity in 124 wild (Europe, Asia, North America) and cultivated (breeding lines and cultivars) hop accessions, and also showed two distinct gene pools European and American, and higher variability within wild North American hop compared to European wild hop and hop cultivars. Štajner et al. [9] also analyzed wild and cultivated hop accessions, determining two main clusters, European and North American, and further separation of each cluster into native and cultivated subgroups. Peredo et al. [40] also found a clear separation between American and European germplasm by analyzing nuclear and chloroplast microsatellite diversity of European and American wild hop and different cultivars, while cultivars showed high similarity to European wild hops, suggesting that they are derived from clonally propagated European plants that have been bred for centuries. Rodolfi et al. [41] used SSR markers to elucidate the genetic diversity of Italian wild hop and to make the comparison with cultivated European and North American commercial cultivars, finding higher genetic diversity of Italian wild populations and a higher number of unique alleles The recent study by Dabbous-Wach et al. [42] combined morphological, chemical, and genetic analyzes to characterize Corsican wild hop and to analyze the agronomic performance of three German cultivars in Corsican environments.

Overall, all these molecular studies have provided insight into the genetic variation of wild and cultivated hop, suggesting low genetic variation in the major hop cultivars, probably because of using a limited number of parents [43].

The increasing demand for hops with new organoleptic characteristics and improved agronomic performance is generating a strong impetus for the development of new varieties. However, the continuous selection of existing breeding material and the use of traditional selection methods, mainly involving progeny from a single cross, impoverishes the genetic diversity of the starting material. Wild germplasm offers new genetic resources for breeding to overcome the limited genetic variation in modern hop breeding programs [8], as they are the source of many important traits in modern hop cultivars, such as disease resistance and alpha acid content [7].

This study focused on assessing the genetic diversity and structure of wild hop populations in the northwestern part of Croatia, a region characterized by a hilly landscape and a large hydrographic network of small streams, tributaries of the Drava and Sava rivers. The water demand of the hop plant for the hop cone yield and the accumulation of secondary metabolites is quite high [44-47]. The riparian areas of northwestern Croatia thus represent an ideal ecosystem for hops and relatively large populations are found there. Therefore, high genetic diversity of these wild hop populations can be expected as it increases with a large effective population size and the decreasing effects of genetic drift according to the neutral theory [48,49]. In contrast to neighboring countries (e.g., Austria, Slovenia), hop was not traditionally cultivated in northwestern Croatia. The only attempt of hop cultivation dates back to the period from 1999 to 2013 in Gregurovec (46.03 N, 16.45 E), but with limited success. Therefore, contamination of the sampled wild populations with cultivated material is highly unlikely. The sampled geographical area has the most intensive agricultural production in Croatia, consisting mainly of arable land (maize, wheat) and temperate deciduous forests. Wild hops as a ruderal species grows in disturbed habitats along field borders, roadsides, and forest edges. At the same time, the northwestern Croatia has the highest rate of urbanization, which poses the greatest threat to biodiversity as the natural habitats of wild hop may decline or even be irretrievably lost. Therefore, the specific objectives of this study were to determine: (1) genetic diversity within and among wild Croatian hop populations; (2) population differentiation and structure of wild hop populations; and (3) recent bottleneck events. The results obtained will be of utmost importance for future hop breeding programs as well as for the conservation of wild hop genetic resources. 


\section{Materials and Methods}

\subsection{Sampling and Plant Material}

A total of 101 individuals from eight wild hop populations were collected in the northwestern part of Croatia, from the areas belonging to the sub-Pannonian microregion of the Pannonian macroregion and partly to the Dinaric macroregion [50]. The sampling sites were chosen to cover uniformly the region of interest. None of the sampling sites were located in natural protected areas. The sampling area of $1 \mathrm{~km}^{2}$ per site was selected and the minimum collection distance between adjacent plants was $250 \mathrm{~m}$ to avoid the sampling of clones [51-53]. Thus, 10 to 15 plants were sampled per each site. Geographical data for each individual were obtained from the station GPS (Figure 1, Table S1). The climatic data on annual mean temperature and annual precipitation of each sampling site were taken from the WorldClim database [54]. The lowest values of mean annual temperature and the highest amount of annual precipitation were recorded for the sampling site of population P1 Ozalj, $9.40{ }^{\circ} \mathrm{C}$ and $1215 \mathrm{~mm}$ respectively, the population sampled at the highest altitude ( $301.20 \mathrm{~m}$ a. s. 1.). The sampling site of P8 Novo Virje is characterized with the highest mean annual temperature $\left(10.80^{\circ} \mathrm{C}\right)$ and the lowest amount of annual precipitation $(776 \mathrm{~mm}$ ) (Table S1). Among the 101 individuals sampled, 38 of them were male and 63 were female plants. Sex ratio (female:male plants) ranged from 1:0.66 in P1 Ozalj to 1:3.33 in P6 Ludbreg, being 1:1.66 across all the populations.

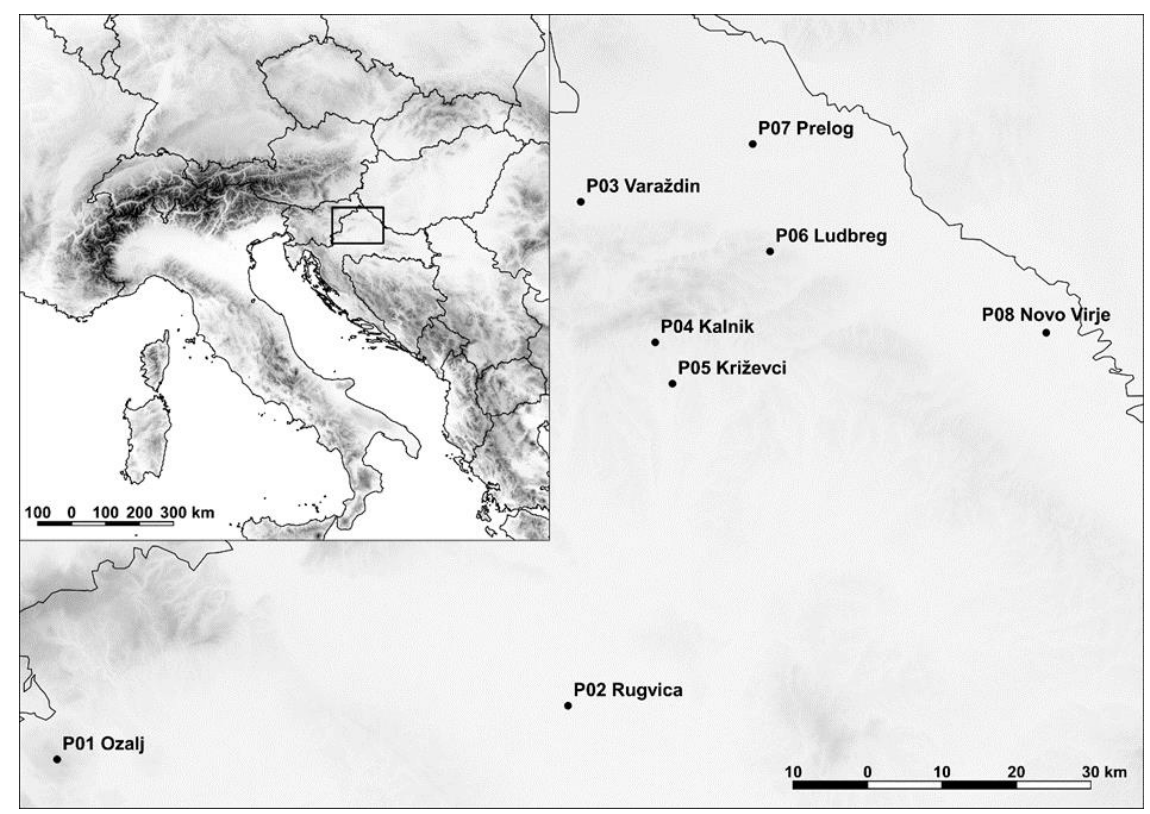

Figure 1. Sampling sites of eight wild hop (Humulus lupulus L.) populations.

\subsection{DNA Extraction and SSR Genotyping}

The DNA was extracted from $25 \mathrm{mg}$ of silica gel dried leaf tissue of 101 individuals from eight wild hop populations, using a DNeasy Plant Mini Kit (Qiagen Inc., Hilden, Germany). DNA concentrations were measured using a P300 NanoPhotometer (Implen Inc., Munich, Germany).

Genetic analysis was performed using 12 genomic microsatellite loci identified in hop (Table 1), according to Jakše et al. [55]. Microsatellite amplification was performed using three multiplex polymerase chain reactions (PCR) in a total volume of $20 \mu \mathrm{L}$ containing $1 \times$ PCR buffer, $1.5 \mathrm{mM} \mathrm{MgCl}, 0.2 \mathrm{mM}$ of each deoxynucleotide triphosphate (dNTP), $0.075 \mu \mathrm{M}$ tail forward primer, $0.2 \mu \mathrm{M}$ tail reverse primer, $0.2 \mu \mathrm{M}$ M13 primer (fluorescently labeled with 6-carboxyfluorescein [6-FAM], 2'-chloro-7' phenyl-1,4-dichloro-6carboxy-fluorescein [VIC], 2'-chloro-5'-fluoro-7' $8^{\prime}$-benzo-1,4-dichloro-6-carboxyfluorescein [NED] or PET [unpublished] dye [Applied Biosystems, Foster City, CA, USA]), 0.5 U of 
TaqHS polymerase (Takara Bio Inc., Shiga, Japan), and 5 ng of template DNA. The amplification was performed with a GeneAmp PCR System 9700 (Applied Biosystems, Foster City, CA, USA) using a two-step PCR protocol with an initial touchdown cycle. The cycling conditions were as follows: $94{ }^{\circ} \mathrm{C}$ for $5 \mathrm{~min}$; followed by five cycles of $45 \mathrm{~s}$ at $94{ }^{\circ} \mathrm{C}, 30 \mathrm{~s}$ of annealing, beginning at $57^{\circ} \mathrm{C}$ and lowered by $1{ }^{\circ} \mathrm{C}$ in each cycle, and $90 \mathrm{~s}$ at $72{ }^{\circ} \mathrm{C} ; 25$ cycles of $45 \mathrm{~s}$ at $94{ }^{\circ} \mathrm{C}, 30 \mathrm{~s}$ at $52^{\circ} \mathrm{C}$ (the first annealing temperature lowered by $5^{\circ} \mathrm{C}$ ), and $90 \mathrm{~s}$ at $72{ }^{\circ} \mathrm{C}$, ending with an 8 -min extension step at $72{ }^{\circ} \mathrm{C}$. The amplification products were run on an ABI 3730XL analyzer (Applied Biosystems, Foster City, CA, USA) by the Macrogen Inc. DNA service (Seoul, Korea) and the results were analyzed with GeneMapper 4.0 software (4.0 version, Applied Biosystems, Foster City, CA, USA, 2005).

Table 1. Informativeness of 12 SSR (Simple Sequence Repeats) markers used in molecular analyses of eight wild hop populations.

\begin{tabular}{|c|c|c|c|c|c|c|c|}
\hline No. & Locus & Fluorophore Label & Repeat Motif & Size Range & $N_{a}$ & PIC & $P I$ \\
\hline M01 & GA4-K16-8 & PET & $(\mathrm{GA})_{16}$ & 190-206 & 5 & 0.604 & 0.176 \\
\hline M02 & GA4-P11-9 & VIC & $(\mathrm{GA})_{18}$ & $217-229$ & 7 & 0.791 & 0.060 \\
\hline M03 & GA5-G3-10 & NED & $(\mathrm{CT})_{22}$ & $123-179$ & 25 & 0.874 & 0.021 \\
\hline M04 & GA6-N13-14 & VIC & $(\mathrm{TC})_{21}$ & $209-271$ & 24 & 0.823 & 0.042 \\
\hline M05 & GA6-N21-14 & NED & $(\mathrm{CT})_{17}$ & $203-219$ & 7 & 0.599 & 0.170 \\
\hline M06 & GA6-P20-14 & PET & $(\mathrm{TC})_{16}$ & $198-206$ & 5 & 0.547 & 0.216 \\
\hline M07 & GA7-07-16 & VIC & $(\mathrm{AG})_{28}$ & $183-227$ & 20 & 0.881 & 0.021 \\
\hline M08 & GA7-16-16 & NED & $(\mathrm{GA})_{16}$ & $218-252$ & 14 & 0.782 & 0.062 \\
\hline M09 & GA7-A6-14 & 6-FAM & $(\mathrm{TC})_{10}$ & $179-191$ & 5 & 0.588 & 0.183 \\
\hline M10 & GA8-K15-4 & 6-FAM & $(\mathrm{CT})_{19}$ & $238-268$ & 12 & 0.794 & 0.057 \\
\hline M11 & GT1-K1-4 & 6-FAM & $(\mathrm{TG})_{10} \mathrm{C}(\mathrm{GT})_{9}$ & $168-220$ & 20 & 0.866 & 0.026 \\
\hline \multirow[t]{2}{*}{ M12 } & GT2-010-8 & PET & $(\mathrm{TA})_{6}(\mathrm{TG})_{16}$ & $188-202$ & 8 & 0.626 & 0.155 \\
\hline & Average & & & & 12.67 & 0.731 & 0.099 \\
\hline
\end{tabular}

$N_{a}$-total number of alleles; PIC-Polymorphism Information Content; PI-Probability of Identity.

\subsection{Data Analysis}

\subsubsection{Microsatellite Diversity}

For each microsatellite locus, the number of alleles per locus $\left(N_{a}\right)$, polymorphic information content $(P I C)$, and probability of identity $(P I)$ were calculated using Cervus v3.0 [56].

\subsubsection{Within-Population Diversity}

The number of distinct multi-locus genotypes was identified using GenClone 2.0 [57]. The pairwise genetic distances among individual samples were calculated based on proportion-of-shared-alleles distance $\left(D_{p s a}\right)$ [58] as implemented in MICROSAT [59].

Data were checked for scoring errors due to stuttering, large allele dropout, and the presence of null alleles using MICRO-CHECKER [60]. Null allele frequencies were estimated by expectation-maximization algorithm [61] using FreeNA [62].

Within-population diversity was assessed by calculating the average number of alleles $\left(N_{a v}\right)$, allelic richness $\left(N_{a r}\right)$, number of private alleles $\left(N_{p r}\right)$, and private allelic richness $\left(N_{\text {par }}\right)$ using HP-Rare [63]. Allelic richness $\left(N_{a r}\right)$ and private allelic richness $\left(N_{\text {par }}\right)$ within each population were estimated after controlling for differences in sample size using the rarefaction method [64]. Population genetic parameters [observed heterozygosity $\left(H_{O}\right)$, expected heterozygosity $\left(H_{E}\right)$, inbreeding coefficient $\left(F_{I S}\right)$ ] were estimated using GENEPOP 4.0 [65]. GENEPOP was also used to test population genotypic frequencies for conformance to Hardy-Weinberg $(H W)$ expectations.

To provide evidence for recent bottleneck events in wild hop populations, observed genetic diversity $\left(H_{E}\right)$ was compared with expected genetic diversity at mutation-drift equilibrium $\left(H_{E Q}\right)$, calculated from the observed number of alleles using the two-phase model (TPM) assuming 22\% multistep changes and a variance of 11.9 , as recommended by Peery et al. [66]. Heterozygote excess was tested by Wilcoxon sign-rank test [67] using BOTTLENECK v1.2.02 [68]. 


\subsubsection{Population Differentiation and Structure}

Genetic differentiation between all population pairs was assessed by calculating pairwise $F_{S T}$ estimates in FSTAT v2.9.3.2 [69]. $p$-values were determined after 10,000 random permutations.

ARLEQUIN v 3.5.2.2 [70] was used to perform analysis of molecular variance (AMOVA; [71]) by partitioning of the total microsatellite diversity among and within wild hop populations. The significance level of $\varphi_{S T}$ was established by a nonparametric randomization test with 10,000 permutations.

The factorial correspondence analysis (FCA) was used to visualize the overall genetic structure using GENETIX v4.05 [72].

Wild hop genetic structure was assessed using STRUCTURE v2.3.4 [73]. The analysis was performed (A) without prior information on the populations to which the individuals belong and (B) with prior information on the populations (LOCPRIOR option) [74]. In both cases thirty runs, consisting of a burn-in period of 200,000 steps followed by 10,000,000 MCMC replicates, were performed, with the number of clusters adjusted from 1 to 11 (K= 1-11; admixture model; correlated allele frequencies). The average estimates (and standard deviations) of the likelihood of the data, $\ln [\operatorname{Pr}(\mathrm{X} \mid \mathrm{K})]$ for each value of $\mathrm{K}$, and the ad hoc statistic $\triangle \mathrm{K}$ [75] were used to select the 'optimal' number of clusters (K) using STRUCTURE HARVESTER v0.6.94 [76]. CLUMPAK [77] was used to cluster and average the runs.

\subsubsection{Isolation by Distance}

The method described by Rousset [78] was used to test the significance of isolation by distance (IBD) among wild hop populations by performing a Mantel's test between the matrix of pairwise $F_{S T} /\left(1-F_{S T}\right)$ ratios and the matrix of the natural logarithm of geographic distances (in $\mathrm{km}$ ) between population pairs using NTSYSpc v2.2 [79].

\section{Results and Discussion}

The identification of genetic diversity and population structure of wild populations represent fundamental steps for the rational use of available genetic resources by providing new insights for their use and conservation. Our study aimed to clarify for the first time the genetic patterns of wild populations of Humulus lupulus L. sampled from the northwestern part of Croatia, by utilizing microsatellite markers.

\subsection{Microsatellite Diversity}

Informativeness of 12 SSR markers used in molecular analyses of eight wild hop populations sampled in Croatia is presented in Table 1. In our study, 12 microsatellites yielded a total of 152 alleles, ranging from 5 (GA4-K16-8, GA6-P20-14, and GA7-A6-14) to 25 (GA5-G3-10), with an average of 12.67 alleles per locus. This is higher than the values obtained in the study by Štajner et al. [9], in which an average of 10.8 alleles per locus was obtained in 67 accessions using 29 SSR markers, but lower than the values obtained by Jakše et al. [39], 15.7 in 124 accessions, or Murakami et al. [35], (14.7 in 133 accessions), but similar to the average number of alleles (12.5) obtained in the study of 12 wild hop populations from Italy [37]. In the analysis of individual loci, the polymorphism information content (PIC) ranged from 0.547 to 0.881 with an average value of 0.731 , which is higher than in the studies mentioned above: 0.635 [39], 0.607 [9], 0.64 [38], and 0.697 [41]. However, comparison with the results of the other studies should be taken with caution, considering that different sets of microsatellite loci were used. In our study, values higher than 0.70 were observed for seven loci (Table 1), indicating their high informativeness in biodiversity studies. The probability of identity (PI) for single locus ranged from 0.021 (M03) to 0.216 (M06) with a combined value of $1.91 \times 10^{-14}$, indicating their usefulness in discriminating among wild hop individuals. 


\subsection{Within-Population Diversity}

The number of distinct multi-locus genotypes corresponded to the number of individuals analyzed, indicating that the sampling strategy used successfully avoided the sampling of clones. The pairwise genetic distance $\left(D_{p s a}\right)$ between 101 sampled individuals ranged from 0.292 (seven different alleles out of 24) to 0.917 (22 different alleles) with an overall average of 0.659 . Average pairwise genetic distances within populations were high in all populations analyzed, ranging from 0.615 (P8 Novo Virje) to 0.669 (P4 Kalnik), suggesting that crosses between relatives and biparental inbreeding are rare in wild hop populations, presumably due to the anemophilic pollen dispersal mechanism [3].

Null alleles were detected in three population/microsatellite locus combinations, out of a total of 96 tests (3.13\%). The null allele frequencies ranged from 0.122 (M11) to 0.180 (M06). All the examined populations were in Hardy-Weinberg equilibrium (HWE) and therefore null alleles were considered unlikely to substantially impact on the results [80]. The main parameters describing the intrapopulation diversity of eight wild hop populations are presented in Table 2. The average number of alleles $\left(N_{a}\right)$ ranged from 6.333 in P3 Varaždin to 7.250 P6 Ludbreg population. Allelic richness $\left(N_{a r}\right)$ varied from 5.955 (P1 Ozalj) to 6.619 (P6 Ludbreg). A large number of private alleles was detected (38 out of 152 in total; $30.4 \%$ ) distributed across all populations. A single private allele was detected in population P2 Rugvica, while the highest abundance of private alleles was detected in population P7 Prelog (10). The high abundance of private alleles in wild accessions has been confirmed in several studies. Jakše et al. [39] reported that compared to cultivated European and North American hop varieties wild hop accessions contained a higher number of private alleles, and this was also confirmed in the study of 80 wild hop accessions from Northern Italy in which 15 private alleles were detected, notably more than in cultivated accessions (6) [41]. Riccioni et al. [37] found 25 private alleles in 12 wild populations from Central Italy. Breeding activities, and thus the selection of desirable traits within the limited genetic base, could lead to a decrease in the number of alleles, especially in low-frequency private alleles in cultivated hop. Private alleles can serve as tools for effective population and cultivar discrimination [81] and help to identify genotypes that could be useful in breeding programs [82].

Table 2. Sampling sites, genetic diversity and genetic bottleneck assessed from 12 microsatellite markers in eight wild Humulus lupulus L. populations.

\begin{tabular}{|c|c|c|c|c|c|c|c|c|c|c|c|c|c|}
\hline No. & Locality & $M$ & $F$ & $n$ & $N_{a}$ & $N_{a r}$ & $N_{p r}$ & $N_{p a r}$ & $H_{O}$ & $H_{E}$ & $F_{I S}$ & & $P_{\text {Bottleneck }}$ \\
\hline P1 & Ozalj & 9 & 6 & 15 & 6.917 & 5.955 & 5 & 0.369 & 0.689 & 0.725 & 0.050 & ns & 0.575 \\
\hline P2 & Rugvica & 5 & 5 & 10 & 6.500 & 6.500 & 1 & 0.168 & 0.767 & 0.769 & 0.004 & ns & 0.235 \\
\hline P3 & Varaždin & 5 & 7 & 12 & 6.333 & 5.992 & 3 & 0.305 & 0.785 & 0.760 & -0.033 & ns & 0.117 \\
\hline P4 & Kalnik & 4 & 8 & 12 & 6.833 & 6.362 & 5 & 0.474 & 0.736 & 0.771 & 0.045 & ns & 0.765 \\
\hline P5 & Križevci & 5 & 10 & 15 & 7.167 & 6.226 & 4 & 0.272 & 0.750 & 0.753 & 0.004 & ns & 0.575 \\
\hline P6 & Ludbreg & 3 & 10 & 13 & 7.250 & 6.619 & 2 & 0.256 & 0.840 & 0.789 & -0.065 & ns & 0.396 \\
\hline P7 & Prelog & 4 & 10 & 14 & 7.000 & 6.240 & 10 & 0.714 & 0.792 & 0.759 & -0.043 & ns & 0.311 \\
\hline \multirow[t]{3}{*}{ P8 } & $\begin{array}{l}\text { Novo } \\
\text { Virje }\end{array}$ & 3 & 7 & 10 & 6.500 & 6.500 & 8 & 0.713 & 0.800 & 0.750 & -0.067 & ns & 0.715 \\
\hline & Average & 4.750 & 7.875 & 12.630 & 6.813 & 6.299 & 4.75 & 0.409 & 0.770 & 0.759 & - & & - \\
\hline & Total & 38 & 63 & 101 & 12.667 & - & 38 & - & 0.767 & 0.768 & 0.001 & & 0.924 \\
\hline
\end{tabular}

$M$-male plants; $F$-female plants; $n$-sample size; $N_{a}$-number of alleles; $N_{a r}$-allelic richness; $N_{p r}$ - total number of private alleles; $N_{\text {par }}$ - private allelic richness; $H_{O}$-observed heterozygosity; $H_{E}$ - expected heterozygosity; $F_{I S}$-inbreeding coefficient $\left({ }^{\text {ns }}\right.$ —non-significant value; $p>0.05$ ). $P_{\text {Bottleneck }}$ - probability of heterozygosity excess using TPM (two-phase model) model indicating population bottleneck.

The data obtained revealed high level of genetic variability in wild hop populations (average $H_{O}=0.770$; average $H_{E}=0.759$ ). Populations shared similar values of observed heterozygosity $\left(H_{O}\right)$ and expected heterozygosity $\left(H_{E}\right)$. The lowest values of both observed and expected heterozygosity were found in population P1 Ozalj $\left(H_{O}=0.689 ; H_{E}=0.725\right)$ and the highest in P6 Ludbreg $\left(H_{O}=0.840 ; H_{E}=0.789\right)$. The slightly higher values of observed heterozygosity in comparison to expected were detected in some of the populations (P3, P6, P7, P8). High phenotypic and alpha-acid content diversity of these wild hop populations was also reported [22]. In a recent investigation of wild hop populations, 
the detected $H_{O}$ and $H_{E}$ were generally lower that the values obtained in our study, e.g., in wild Iranian hop populations $H_{O}$ ranged from 0.31 to 0.82 , and $H_{E}$ ranged from 0.34 to 0.75 [38]. Furthermore, in wild populations from Central Italy Riccioni et al. [37] observed $H_{O}$ ranging from 0.522 to 0.656 and $H_{E}$ ranging from 0.505 to 0.654 . The outcrossing nature of this dioecious species and the predominant wind pollination mode [3] are probably responsible for the high genetic variation observed in wild hop populations in general. The patterns found are consistent with expectations for outcrossing wind-pollinated species and those with a wide geographical range $[83,84]$. Riccioni et al. [37] suggest that hop seeds may also be frequently dispersed by water, as hop inhabits the area between terrestrial and freshwater ecosystems, thus further promoting gene flow among populations.

HWE was observed in all analyzed populations as the multilocus estimates of Wright's inbreeding coefficients $\left(F_{I S}\right)$ showed no significant deviation from zero $(p>0.05)$. The heterozygosity-excess method implemented in BOTTLENECK (Wilcoxon signed rank test assuming a two-phased model) did not identify significant bottleneck in any of the studied populations.

Treating all sampled plants as a single population, justified by lack of population differentiation (see below), the observed heterozygosity $\left(H_{O}=0.767\right)$ was almost equal to the expected one $\left(H_{E}=0.768\right)$ and the inbreeding coefficient $\left(F_{I S}=0.001\right)$ was not significant. The same was true for the probability of heterozygosity excess as a sign of recent bottleneck events $\left(P_{\text {Bottleneck }}=0.924\right)$.

\subsection{Population Differentiation and Structure}

Due to the anemophilic pollen dispersal mechanism, an increasing degree of differentiation correlated with geographical distance was anticipated. However, the results showed a low degree of genetic differentiation among populations and no evidence of geographic structuring across the sampled distribution of the species. No differentiation was observed between populations P7 Prelog and P3 Varaždin, as well as between P8 Novo Virje and P3 Varaždin, and P8 Novo Virje and P5 Križevci $\left(F_{S T}=0.00\right)$. The highest value of genetic differentiation was observed between populations P1 Ozalj, sampled from the southwestern part and P7 Prelog, sampled in the northern parts of the sampled area, the two populations most distant from each other. Only one pairwise $F_{S T}$ between populations P1 Ozalj and P7 Prelog was significant $(0.01<p<0.05$ after 10,000 permutations) (Table S2). The data obtained suggest pollen-mediated connectivity which reduces $F_{S T}$ through increased pollen flow. The high gene flow between populations of $H$. lupulus occurs at sufficient levels to minimize genetic difference. The low degree of genetic divergence among the studied populations can also be explained by a common genetic pool and the absence of differential selection pressure. High levels of gene flow allow for the maintenance of high genetic diversity and are expected to maintain genetic consistency among populations, reducing genetic divergence among populations [85]. Low gene flow rates are thought to produce genetic differentiation through genetic drift and selection [86].

Most of the total genetic diversity resulted from differences between individuals within populations $(98.64 \%)$, indicating weak differentiation among populations $\left(\varphi_{S T}=0.014\right)$, although still significant after 10,000 permutations $(p<0.0001)$, following the Analysis of Molecular Variance (AMOVA) approach. This is consistent with predictions that crosspollinating species with wind-dispersed pollen mechanism retain most of the genetic variation within populations [87], as the distribution of genetic variability within and among populations greatly depends on the breeding system in particular plant populations [88].

The results of the factorial correspondence analysis (FCA) revealed various aspects of microsatellite diversity in hop, indicating some degree of differentiation among populations. Figure 2 presents the projection of individuals and population barycenters onto the plane defined by the first two axes of the FCA. The first two axes accounted for 19.44 and $17.37 \%$ of the total inertia, respectively. The first axes separated most of the hop individuals from the southwestern population P1 Ozalj from the northern populations (P3 Varaždin, 
P4 Kalnik and P7 Prelog). The second axes separated the northernmost populations P6 Ludberg and the northeastern population P8 Novo Virje from the southwestern population P1 Ozalj and the southeastern population P2 Rugvica. Some individuals were drawn far from the barycenter of the original population, suggests the admixed origin of populations.

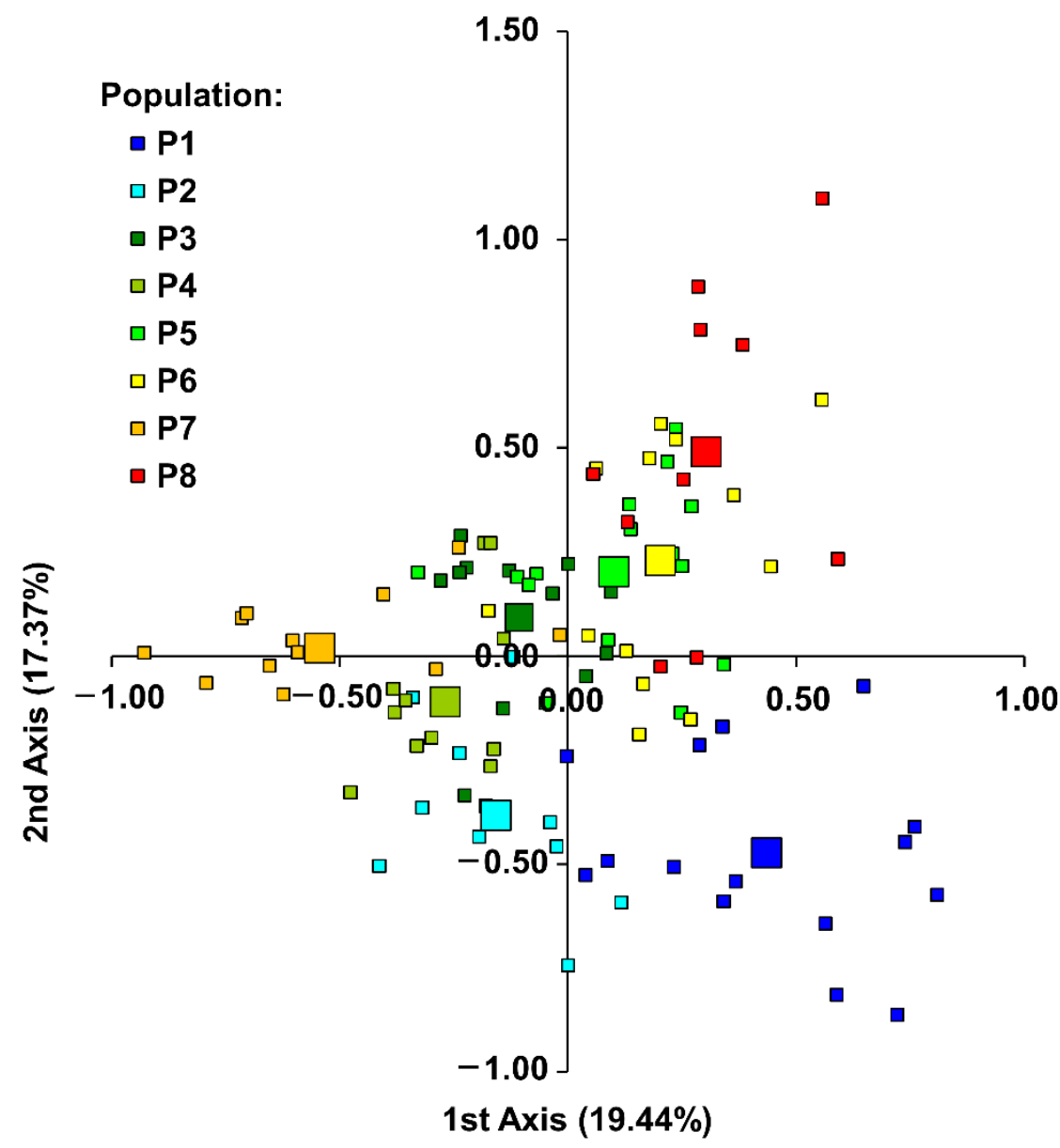

Figure 2. Factorial correspondence analysis plot showing the genetic relationships among wild hop samples $(n=101)$ from eight populations in Croatia. Each individual genotype is indicated by a small symbol, while population barycenters are represented by larger ones.

Using Bayesian model-based clustering as implemented in STRUCTURE, without prior information on the populations to which the individuals belong (i.e., without LOCPRIOR option), the highest likelihood of the data $(\ln \operatorname{Pr}(\mathrm{X} \mid \mathrm{K})=-4453.20)$ and the highest average likelihood ( -4454.19$)$ were obtained at $K=1$, indicating the absence of any population structure (Figure S1A). The highest $\Delta \mathrm{K}$ values were observed for $\mathrm{K}=5$ (3.65), followed by that of $K=4(2.50)$. However, the analyses did not yield a biologically meaningful result for any value of $K$, as shown in Figure S2A. Between $97 \%$ (for $K=3$ ) and $100 \%$ (for $K=2, K=10$, $\mathrm{K}=11$ ) of individuals would be considered "mixed" with membership probabilities of less than $75 \%$ for each cluster from $\mathrm{K}=2$ to $\mathrm{K}=11$ (Figure S2A). Using population membership as an informative prior (i.e., with the LOCPRIOR option), the highest likelihood of the data $(\ln \mathrm{P}(\mathrm{X} \mid \mathrm{K})=-4442.3)$ was obtained at $\mathrm{K}=2$, while the highest average likelihood (-4454.18) was obtained at $\mathrm{K}=1$ (Figure S1B). Similarly, to the previous analysis, the highest $\Delta K$ values were observed for $K=5$ (1.22), followed by that of $K=4$ (1.10), but this led to results without clear biological interpretation, as shown in Figure S2B. At K = 2, 76 out of 101 individuals were assigned to cluster $\mathrm{C} 1$ with membership probabilities greater than $75 \%$, while a single individual was assigned to cluster $C 2(Q>0.75)$ and the rest would be considered "mixed" $(\mathrm{Q}<0.75)$. In all cases from $\mathrm{K}=3$ to $\mathrm{K}=11$, no individual 
was assigned to a cluster with membership probabilities greater than $75 \%$ (Figure S2B). The correlation between the matrices of genetic $\left(F_{S T} /\left(1-F_{S T}\right)\right.$ ratios) and geographic $(\ln (\mathrm{km}))$ distances was moderate but not significant $(r=0.352 ; p=0$. 105) (Figure S3). Therefore, no isolation by distance could be detected, confirming once again the extensive gene flow among populations.

In contrast to our results, other studies dealing with wild hop accession showed the existence of strong structuring. Riccioni et al. [37] detected five distinct hop gene pools in Central Italy and significant isolation by distance, which also revealed genetic structure between geographically close populations. Five genetic clusters were also identified by Mafakheri et al. [38], but the grouping of hop genotypes did not correspond to their geographical origin. On a large geographical scale, several studies showed clustering of hop accessions that partially coincided with their geographic origin. In the study that included wild hop accessions from Canada, the Caucasus, Europe, and North America, Patzak et al. [36] identified two main clusters corresponding to their geographical origin: North American and Euroasian, the latter being further subdivided into two subgroups, the first of which included wild genotypes from continental Europe and the second from the Caucasus region, confirming the results of Murakami et al. [35]. However, no relationship was found between the clustering of the European hop genotypes and their geographical origin, as was the case for the Caucasian wild populations, confirming the overlapping variability in the European wild accessions and the close genetic relationship. The same results were obtained in this study, but on a smaller geographical scale.

\section{Conclusions}

Germplasm diversity assessment helps in identifying genotypes useful in crop improvement programs whose effectiveness depends on the availability of various genetic resources. The results obtained indicate a high level of genetic diversity in wild populations of Humulus lupulus L. and a low level of genetic differentiation among populations. Therefore, extensive sampling per population is clearly required to assess the genetic diversity of hop populations. Sampling strategies involving sampling across a large number of localities represented by only a few samples could lead to erroneous conclusions. In addition, there appears to be no isolation by distance between populations separated by up to 150 $\mathrm{km}$. The results obtained indicate that there is a persistent gene flow between populations and that genetic material is frequently exchanged between populations, despite the fact that the sampling area is one of the most populated and infrastructurally developed regions in Croatia. The results show great potential of wild hop populations from Croatia for use in future breeding programs. Further studies will aim to sample the entire distribution range of wild hop in Croatia to gain better insight into genetic, morphological, and chemical variability in order to select the best performing genotypes for the development of new varieties.

Supplementary Materials: The following are available online at https:/ / www.mdpi.com/article/10 .3390/app11146484/s1, Table S1: Geographical and climatic data of eight wild hop sampling sites in northwestern Croatia, Table S2: Pairwise $F_{S T}$ values between wild hop populations (lower diagonal) and their significance (upper diagonal). $\mathrm{ns}=$ non-significant value; ${ }^{*}=$ significant at $0.01<p<0.05$, Table S3: Microsatellite data of eight wild hop populations in northwestern Croatia, Figure S1: Log-likelihood values $[\ln \operatorname{Pr}(\mathrm{X} \mid \mathrm{K})]$ for each of the thirty independent runs of each $\mathrm{K}$ and $\Delta \mathrm{K}$ values for each $\mathrm{K}$ as inferred from microsatellite data of wild hop samples performed (A) without prior information on the populations to which the individuals belong and (B) with prior information on the populations (LOCPRIOR option) using STRUCTURE, Figure S2: Genetic structure of wild hop populations based on STRUCTURE analysis of microsatellite data for $K=1$ to 5 performed (A) without prior information on the populations to which the individuals belong and (B) with prior information on the populations (LOCPRIOR option). Each vertical bar represents an individual genotype, with the probability of membership $(\mathrm{Q})$ to genetic clusters differentiated by colour, Figure S3: Isolationby-distance (IBD) plot showing the relationship between pairwise geographic $[\ln (\mathrm{km})]$ and genetic $\left(F_{S T} / 1-F_{S T}\right)$ distances between eight wild hop populations in Croatia. 
Author Contributions: Conceptualization, S.S. and Z.Š.; methodology, Z.Š., S.S., J.J. and Z.L.; formal analysis, Z.Š., Z.L., F.V.; investigation, S.S., Z.Š., R.E.; writing—original draft preparation, M.G., Z.Š., S.S., F.V.; writing-review and editing, M.G., Z.Š., S.S. and J.J. All authors have read and agreed to the published version of the manuscript.

Funding: This research received no external funding.

Institutional Review Board Statement: Not applicable.

Informed Consent Statement: Not applicable.

Data Availability Statement: The data presented in this study are available in [Table S3].

Conflicts of Interest: The authors declare no conflict of interest.

\section{References}

1. Wilson, D.G. Plant Remains From the Graveney Boat and the Early History of Humulus Lupulus L. in W. Europe. New Phytol. 1975, 75, 627-648. [CrossRef]

2. Behre, K.-E. The history of beer additives in Europe-A review. Veg. Hist. Archaeobot. 1999, 8, 35-48. [CrossRef]

3. Small, E. A Numerical and Nomenclatural Analysis of Morpho-Geographic Taxa of Humulus. Syst. Bot. 1978, 3, 37-76. [CrossRef]

4. Burgess, A.H. Hops: Botany, Cultivation and Utilization; Leonard Hill Ltd.: London, UK, 1964.

5. Delyser, D.Y.; Kasper, W.J. Hopped Beer: The Case For Cultivation. Econ. Bot. 1994, 48, 166-170. [CrossRef]

6. Chadwick, L.R.; Pauli, G.F.; Farnsworth, N.R. The pharmacognosy of Humulus lupulus L. (hops) with an emphasis on estrogenic properties. Phytomedicine 2006, 13, 119-131. [CrossRef] [PubMed]

7. Neve, R.A. Hops; Chapman and Hall: London, UK, 1991; ISBN 978-0-412-30330-2.

8. Patzak, J.; Nesvadba, V.; Henychová, A.; Krofta, K. Assessment of the genetic diversity of wild hops (Humulus lupulus L.) in Europe using chemical and molecular analyses. Biochem. Syst. Ecol. 2010, 38, 136-145. [CrossRef]

9. Štajner, N.; Šatović, Z.; Čerenak, A.; Javornik, B. Genetic structure and differentiation in hop (Humulus lupulus L.) as inferred from microsatellites. Euphytica 2008, 161, 301-311. [CrossRef]

10. Shephard, H.L.; Parker, J.S.; Darby, P.; Ainsworth, C.C. Sexual development and sex chromosomes in hop. New Phytol. 2000, 148, 397-411. [CrossRef] [PubMed]

11. Čerenak, A.; Pavlovič, M.; Luskar, M.; Košir, I. Characterization of slovenian hop (Humulus lupulus L.) varieties by analysis of essential oil. Hop Bull. 2011, 18, 27-32.

12. Negri, G.; di Santi, D.; Tabach, R. Bitter acids from hydroethanolic extracts of Humulus lupulus L., Cannabaceae, used as anxiolytic. Rev. Bras. Farmacogn. 2010, 20, 850-859. [CrossRef]

13. Van Cleemput, M.; Cattoor, K.; De Bosscher, K.; Haegeman, G.; De Keukeleire, D.; Heyerick, A. Hop (Humulus lupulus)-derived bitter acids as multipotent bioactive compounds. J. Nat. Prod. 2009, 72, 1220-1230. [CrossRef] [PubMed]

14. Zanoli, P.; Zavatti, M.; Rivasi, M.; Brusiani, F.; Losi, G.; Puia, G.; Avallone, R.; Baraldi, M. Evidence that the $\beta$-acids fraction of hops reduces central GABAergic neurotransmission. J. Ethnopharmacol. 2007, 109, 87-92. [CrossRef]

15. Zanoli, P.; Zavatti, M. Pharmacognostic and pharmacological profile of Humulus lupulus L. J. Ethnopharmacol. 2008, 116, 383-396. [CrossRef]

16. Kac, J.; Plazar, J.; Mlinarič, A.; Žegura, B.; Lah, T.T.; Filipič, M. Antimutagenicity of hops (Humulus lupulus L.): Bioassay-directed fractionation and isolation of xanthohumol. Phytomedicine 2008, 15, 216-220. [CrossRef]

17. Gerhäuser, C. Beer constituents as potential cancer chemopreventive agents. Eur. J. Cancer 2005, 41, 1941-1954. [CrossRef]

18. Jirovetz, L.; Bail, S.; Buchbauer, G.; Denkova, Z.; Slavchev, A.; Stoyanova, A.; Schmidt, E.; Geissler, M. Antimicrobial testings, gas chromatographic analysis and olfactory evaluation of an essential oil of hop cones (Humulus lupulus L.) from Bavaria and some of its main compounds. Sci. Pharm. 2006, 74, 189-201. [CrossRef]

19. Tofană, M.; Socaci, S.A.; Socaciu, C.; Mihăiescu, D.E.; Semeniuc, C.; Truţa, D. Optimization of HS/GC-MS Method for the Determination of Volatile Compounds from some Indigenous Hop Varieties. Bull. Univ. Agric. Sci. Vet. Med. Cluj-Napoca Agric. 2009, 66, 1843-5386. [CrossRef]

20. Liu, M.; Zeng, Z.; Xiong, B. Preparation of novel solid-phase microextraction fibers by sol-gel technology for headspace solidphase microextraction-gas chromatographic analysis of aroma compounds in beer. J. Chromatogr. A 2005, 1065, 287-299. [CrossRef] [PubMed]

21. Pinho, O.; Ferreira, I.M.P.L.V.O.; Santos, L.H.M.L.M. Method optimization by solid-phase microextraction in combination with gas chromatography with mass spectrometry for analysis of beer volatile fraction. J. Chromatogr. A 2006, 1121, 145-153. [CrossRef]

22. Srečec, S.; Zechner-Krpan, V.; Petravić-Tominac, V.; Čerenak, A.; Liber, Z.; Šatović, Z. Phenotypic and alpha-acid content diversity of wild hop populations in Croatia. Plant Soil Environ. 2010, 56, 37-42. [CrossRef]

23. Nance, M.R.; Setzer, W.N. Volatile components of aroma hops (Humulus lupulus L.) commonly used in beer brewing. J. Brew. Distill. 2011, 2, 16-22. 
24. Mongelli, A.; Rodolfi, M.; Ganino, T.; Marieschi, M.; Dall'Asta, C.; Bruni, R. Italian hop germplasm: Characterization of wild Humulus lupulus L. genotypes from Northern Italy by means of phytochemical, morphological traits and multivariate data analysis. Ind. Crops Prod. 2015, 70, 16-27. [CrossRef]

25. Čeh, B.; Kač, M.; Košir, I.J.; Abram, V. Relationships between Xanthohumol and Polyphenol Content in Hop Leaves and Hop Cones with Regard to Water Supply and Cultivar. Int. J. Mol. Sci. 2007, 8, 989. [CrossRef]

26. Okada, Y.; Ito, K. Cloning and analysis of valerophenone synthase gene expressed specifically in lupulin gland of hop (Humulus lupulus L.). Biosci. Biotechnol. Biochem. 2001, 65, 150-155. [CrossRef] [PubMed]

27. Jakše, J.; Bandelj, D.; Javornik, B. Eleven new microsatellites for hop (Humulus lupulus L.). Mol. Ecol. Notes 2002, 2, 544-546. [CrossRef]

28. McAdam, E.L.; Vaillancourt, R.E.; Koutoulis, A.; Whittock, S.P. Quantitative genetic parameters for yield, plant growth and cone chemical traits in hop (Humulus lupulus L.). BMC Genet. 2014, 15, 1-18. [CrossRef]

29. Shephard, H.; Parker, J.; Darby, P.; Charles, C.A. Sex expression in hop (Humulus lupulus L. and H.japonicus Sieb. et Zucc.) floral morphology and sex chromosomes. In Sex Determination in Plants; Ainsworth, C.C., Ed.; BIOS Scientific Publishers Ltd.: Oxford, UK, 1999; pp. 139-150.

30. McKey, D.; Elias, M.; Pujol, M.E.; Duputié, A. The evolutionary ecology of clonally propagated domesticated plants. Nezw Phytol. 2010, 186, 318-332. [CrossRef]

31. Šuštar-Vozlič, J.; Javornik, B. Genetic relationships in cultivars of hop, Humulus lupulus L., determined by RAPD analysis. Plant Breed. 1999, 118, 175-181. [CrossRef]

32. Murakami, A. Hop variety classification using the genetic distance based on RAPD. J. Inst. Brew. 2000, 106, 157-162. [CrossRef]

33. Henning, J.A.; Steiner, J.J.; Hummer, K.E. Genetic diversity among world hop accessions grown in the USA. Crop Sci. 2004, 44, 411-417. [CrossRef]

34. Seefelder, S.; Ehrmaier, H.; Schweizer, G.; Seigner, E. Genetic diversity and phylogenetic relationships among accessions of hop, Humulus lupulus, as determined by amplified fragment length polymorphism fingerprinting compared with pedigree data. Plant Breed. 2000, 119, 257-263. [CrossRef]

35. Murakami, A.; Darby, P.; Javornik, B.; Pais, M.S.S.; Seigner, E.; Lutz, A.; Svoboda, P. Microsatellite DNA analysis of wild hops, Humulus lupulus L. Genet. Resour. Crop Evol. 2006, 53, 1553-1562. [CrossRef]

36. Patzak, J.; Nesvadba, V.; Krofta, K.; Henychova, A.; Marzoev, A.I.; Richards, K. Evaluation of genetic variability of wild hops (Humulus lupulus L.) in Canada and the Caucasus region by chemical and molecular methods. Genome 2010, 53, 545-557. [CrossRef]

37. Riccioni, C.; Belfiori, B.; Sileoni, V.; Marconi, O.; Perretti, G.; Bellucci, M.; Rubini, A. High genetic and chemical diversity of wild hop populations from Central Italy with signals of a genetic structure influenced by both sexual and asexual reproduction. Plant Sci. 2021, 304, 110794. [CrossRef]

38. Mafakheri, M.; Kordrostami, M.; Rahimi, M.; Matthews, P.D. Evaluating genetic diversity and structure of a wild hop (Humulus lupulus L.) germplasm using morphological and molecular characteristics. Euphytica 2020, 216, 1-19. [CrossRef]

39. Jakše, J.; Šatović, Z.; Javornik, B. Microsatellite variability among wild and cultivated hops (Humulus lupulus L.). Genome 2004, 47, 889-899. [CrossRef]

40. Peredo, E.L.; Revilla, M.Á.; Reed, B.M.; Javornik, B.; Cires, E.; Prieto, J.A.F.; Arroyo-García, R. The influence of European and American wild germplasm in hop (Humulus lupulus L.) cultivars. Genet. Resour. Crop Evol. 2010, 57, 575-586. [CrossRef]

41. Rodolfi, M.; Silvanini, A.; Chiancone, B.; Marieschi, M.; Fabbri, A.; Bruni, R.; Ganino, T. Identification and genetic structure of wild Italian Humulus lupulus L. and comparison with European and American hop cultivars using nuclear microsatellite markers. Genet. Resour. Crop Evol. 2018, 65, 1405-1422. [CrossRef]

42. Dabbous-Wach, A.; Rodolfi, M.; Paolini, J.; Costa, J.; Ganino, T. Characterization of wild corsican hops and assessment of the performances of german hops in corsican environmental conditions through a multidisciplinary approach. Appl. Sci. 2021, 11, 3756. [CrossRef]

43. Jakše, J.; Kindlhofer, K.; Javornik, B. Assessment of genetic variation and differentiation of hop genotypes by microsatellite and AFLP markers. Genome 2001, 44, 773-782. [CrossRef] [PubMed]

44. Srečec, S.; Kvaternjak, I.; Kaučić, D.; Špoljar, A.; Erhatić, R. Influence of Climatic Conditions on Accumulation of $\alpha$-acids in Hop Cones. Agric. Conspec. Sci. 2008, 73, 161-166.

45. Pavlovic, M.; Pavlovic, V.; Rozman, C.; Udovc, A.; Stajnko, D.; Wang, D.; Gavric, M.; Srecec, S. Market value assessment of hops by modeling of weather attributes. Plant Soil Environ. 2013, 59, 267-272. [CrossRef]

46. Rossini, F.; Loreti, P.; Provenzano, M.E.; De Santis, D.; Ruggeri, R. Agronomic performance and beer quality assessment of twenty hop cultivars grown in central Italy. Ital. J. Agron. 2016, 11, 180-187. [CrossRef]

47. Mackinnon, D.; Pavlovič, V.; Čeh, B.; Naglič, B.; Pavlovič, M. The impact of weather conditions on alpha-acid content in hop (Humulus lupulus L.) cv. aurora. Plant Soil Environ. 2020, 66, 519-525. [CrossRef]

48. Kimura, M. The Neutral Theory of Molecular Evolution; Cambridge University Press: Cambridge, MA, USA; New York, NY, USA, 1983.

49. Hague, M.T.J.; Routman, E.J. Does population size affect genetic diversity? A test with sympatric lizard species. Heredity 2015, 116, 92-98. [CrossRef] 
50. Wagner, T. Autochthonous Hop in Yugoslavia and Its Usability for Breeding New Varieties in Comparison with the Grown in Present; Institute of Hop Research: Žalec, Slovenia, 1974.

51. Kišgeci, J.; Mijavec, A.; Aćimović, M.; Spevak, P.; Vučić, N. Hmeljarstvo; Faculty of Agriculture-Institute of Field and Vegetable Crops: Novi Sad, Serbia, 1984.

52. Rybáček, V. Hop Production; SZN: Prague, Czech Republic, 1991.

53. Srečec, S. Hmeljarstvo; Križevci College of Agriculture: Križevci, Croatia, 2004.

54. Hijmans, R.J.; Cameron, S.E.; Parra, J.L.; Jones, P.G.; Jarvis, A. Very high resolution interpolated climate surfaces for global land areas. Int. J. Climatol. 2005, 25, 1965-1978. [CrossRef]

55. Jakše, J.; Luthar, Z.; Javornik, B. New polymorphic dinucleotide and trinucleotide microsatellite loci for hop Humulus lupulus L. Mol. Ecol. Resour. 2008, 8, 769-772. [CrossRef] [PubMed]

56. Kalinowski, S.T.; Taper, M.L.; Marshall, T.C. Revising how the computer program CERVUS accommodates genotyping error increases success in paternity assignment. Mol. Ecol. 2007, 16, 1099-1106. [CrossRef]

57. Arnaud-Haond, S.; Belkhir, K. GENCLONE: A computer program to analyse genotypic data, test for clonality and describe spatial clonal organization. Mol. Ecol. Notes 2007, 7, 15-17. [CrossRef]

58. Bowcock, A.M.; Ruiz-Linares, A.; Tomfohrde, J.; Minch, E.; Kidd, J.R.; Cavalli-Sforza, L.L. High resolution of human evolutionary trees with polymorphic microsatellites. Nature 1994, 368, 455-457. [CrossRef] [PubMed]

59. Minch, E.; Ruiz-Linares, A.; Goldstein, D.; Feldman, M.; Cavalli-Sforza, L.L. MICROSAT: A Computer Program for Calculating Various Statistics on Microsatellite Allele Data; Version 1.5; Stanford University: Stanford, CA, USA, 1997.

60. Van Oosterhout, C.; Hutchinson, W.F.; Wills, D.P.M.; Shipley, P. MICRO-CHECKER: Software for identifying and correcting genotyping errors in microsatellite data. Mol. Ecol. Notes 2004, 4, 535-538. [CrossRef]

61. Dempster, A.P.; Laird, N.M.; Rubin, D.B. Maximum Likelihood from Incomplete Data Via the EM Algorithm. J. R. Stat. Soc. Ser. B 1977, 39, 1-22. [CrossRef]

62. Chapuis, M.P.; Estoup, A. Microsatellite null alleles and estimation of population differentiation. Mol. Biol. Evol. 2007, 24, 621-631. [CrossRef] [PubMed]

63. Kalinowski, S.T. HP-RARE 1.0: A computer program for performing rarefaction on measures of allelic richness. Mol. Ecol. Notes 2005, 5, 187-189. [CrossRef]

64. Kalinowski, S.T. Counting Alleles with Rarefaction: Private Alleles and Hierarchical Sampling Designs. Conserv. Genet. 2004, 5, 539-543. [CrossRef]

65. Raymond, M.; Rousset, F. GENEPOP (Version 1.2): Population Genetics Software for Exact Tests and Ecumenicism. J. Hered. 1995, 86, 248-249. [CrossRef]

66. Zachariah Peery, M.; Kirby, R.; Reid, B.N.; Stoelting, R.; Doucet-Bëer, E.; Robinson, S.; Vásquez-Carrillo, C.; Pauli, J.N.; Palsboll, P.J. Reliability of genetic bottleneck tests for detecting recent population declines. Mol. Ecol. 2012, 21, 3403-3418. [CrossRef]

67. Luikart, G.; Allendorf, F.W.; Cornuet, J.M.; Sherwin, W.B. Distortion of allele frequency distributions provides a test for recent population bottlenecks. J. Hered. 1998, 89, 238-247. [CrossRef]

68. Cornuet, J.M.; Luikart, G. Description and power analysis of two tests for detecting recent population bottlenecks from allele frequency data. Genetics 1996, 144, 2001-2014. [CrossRef]

69. Goudet, J. FSTAT (Version 1.2): A Computer Program to Calculate F-statistics. J. Hered. 1995, 86, 485-486. [CrossRef]

70. Excoffier, L.; Lischer, H.E.L. Arlequin suite ver 3.5: A new series of programs to perform population genetics analyses under Linux and Windows. Mol. Ecol. Resour. 2010, 10, 564-567. [CrossRef]

71. Excoffier, L.; Smouse, P.E.; Quattro, J.M. Analysis of molecular variance inferred from metric distances among DNA haplotypes: Application to human mitochondrial DNA restriction data. Genetics 1992, 131, 479-491. [CrossRef]

72. Belkhir, K.; Borsa, P.; Chikhi, L.; Raufaste, N.; Bonhomme, F. GENETIX 4.05, Logiciel Sous Windows TM pour la Génétique des Populations. Laboratoire Génome, Populations, Interactions, CNRS UMR 5000; Université de Montpellier II: Montpellier, France, 2004.

73. Pritchard, J.K.; Stephens, M.; Donnelly, P. Inference of population structure using multilocus genotype data. Genetics 2000, 155, 945-959. [CrossRef]

74. Hubisz, M.J.; Falush, D.; Stephens, M.; Pritchard, J.K. Inferring weak population structure with the assistance of sample group information. Mol. Ecol. Resour. 2009, 9, 1322. [CrossRef] [PubMed]

75. Evanno, G.; Regnaut, S.; Goudet, J. Detecting the number of clusters of individuals using the software STRUCTURE: A simulation study. Mol. Ecol. 2005, 14, 2611-2620. [CrossRef]

76. Earl, D.A.; vonHoldt, B.M. STRUCTURE HARVESTER: A website and program for visualizing STRUCTURE output and implementing the Evanno method. Conserv. Genet. Resour. 2012, 4, 359-361. [CrossRef]

77. Kopelman, N.M.; Mayzel, J.; Jakobsson, M.; Rosenberg, N.A.; Mayrose, I. Clumpak: A program for identifying clustering modes and packaging population structure inferences across K. Mol. Ecol. Resour. 2015, 15, 1179-1191. [CrossRef]

78. Rousset, F. Genetic differentiation and estimation of gene flow from F-statistics under isolation by distance. Genetics 1997, 145, 1219-1228. [CrossRef]

79. Rohlf, F.J. NTSYS-pc. Version 2.2. Numerical Taxonomy and Multivariate Analysis System; Applied Biostatistics Inc.: New York, NY, USA, 2000.

80. Carlsson, J. Effects of microsatellite null alleles on assignment testing. J. Hered. 2008, 99, 616-623. [CrossRef] 
81. Čerenak, A.; Jakše, J.; Javornik, B. Identification and Differentiation of Hop Varieties Using Simple Sequence Repeat Markers. J. Am. Soc. Brew. Chem. 2004, 62, 1-7. [CrossRef]

82. Park, Y.-J.; Dixit, A.; Ma, K.-H.; Lee, J.-K.; Lee, M.-H.; Chung, C.-S.; Nitta, M.; Okuno, K.; Kim, T.-S.; Cho, E.-G.; et al. Evaluation of genetic diversity and relationships within an on-farm collection of Perilla frutescens (L.) Britt. using microsatellite markers. Genet. Resour. Crop Evol. 2008, 55, 523-535. [CrossRef]

83. Hamrick, J.L.; Godt, M.J.W. Allozyme diversity in plant species. In Plant Population Genetics, Breeding, and Genetic Resources; Brown, A.H.D., Clegg, M.T., Kahler, A.L., Weir, B.S., Eds.; Sinauer Associates Inc.: Sunderland, MA, USA, 1990 ; pp. 43-63. ISBN 0878931171

84. Nybom, H. Comparison of different nuclear DNA markers for estimating intraspecific genetic diversity in plants. Mol. Ecol. 2004, 13, 1143-1155. [CrossRef] [PubMed]

85. Millar, C.I.; Libby, W.J. Strategies for Conserving Clinal, Ecotypic, and Disjunct Population Diversiv in Widespread Species. In Genetics and Conservation of Rare Plants; Falk, D.A., Holsinger, K.E., Eds.; Oxford University Press: Oxford, UK, 1991.

86. Bittencourt, J.V.M.; Sebbenn, A.M. Patterns of pollen and seed dispersal in a small, fragmented population of the wind-pollinated tree Araucaria angustifolia in southern Brazil. Heredity (Edinb.) 2007, 99, 580-591. [CrossRef] [PubMed]

87. Hamrick, J.L.; Godt, M.J.W. Effects of Life History Traits on Genetic Diversity in Plant Species. Philos. Trans. Biol. Sci. 1996, 351, 1291-1298.

88. Nybom, H.; Bartish, I.V. Effects of life history traits and sampling strategies on genetic diversity estimates obtained with RAPD markers in plants. Perspect. Plant Ecol. Evol. Syst. 2000, 3, 93-114. [CrossRef] 